\title{
Microbiology culture results in high risk foot clinic patients: an audit
}

\author{
Jessica M White ${ }^{1 *}$, Lynne Toh², Hugh G Dickson³ , Erika N Koo ${ }^{1}$, Gentry S Winters', Marion G Harpur', \\ John Widdup ${ }^{1}$, Namson S Lau ${ }^{3}$ \\ From Australasian Podiatry Council Conference 2011 \\ Melbourne, Australia. 26-29 April 2011
}

\section{Background}

The majority of the clinical work of a high risk foot service is involved in the care of patients with diabetic foot ulcers. Infection is common, with the percentage of patients in a session receiving antibiotics ranging from $50-100 \%$. We conducted an audit of microbiology culture results for our patients over a one-year period.

\section{Methods}

Three reviewers extracted all microbiology results for all patients who had a current foot progress chart and who had been attending the high risk foot unit at Liverpool Hospital from the period of 15 September 2009 to 15 September 2010. The results were collated and entered into an $\mathrm{Excel}^{\odot}$ spread sheet. Fields included wound location, microbes, colonisation, and antibiotic susceptibility.

\section{Results}

The total number of patients fitting the selection criteria was 131 . The most common finding was coliform colonisation, in 83 patients (63.4\%), followed by staphylococcus aureus, in 57 patients (43.5\%), MRSA, in 21 patients (16\%), and streptococcus (Group A, B, C, G) in 14 patients $(10 \%)$. Less common organisms included acinetobacter baumanii, and klebsiella oxytoca.

\section{Conclusions}

The high incidence of MRSA in our patient population is of concern, especially as the choice of antibiotics available to treat infections with this organism is slowly becoming reduced. Major areas of lack of knowledge in the care of patients with foot ulceration include the

\footnotetext{
* Correspondence: jessica.white@sswahs.nsw.gov.au

'Department of Podiatry, Liverpool Hospital, Locked Bag 7103, Liverpool,

NSW, 2170, Australia

Full list of author information is available at the end of the article
}

optimal duration of antibiotic treatment, both oral and parenteral, for infected ulcers and osteomyelitis in diabetic patients.

\section{Author details}

'Department of Podiatry, Liverpool Hospital, Locked Bag 7103, Liverpool, NSW, 2170, Australia. ${ }^{2}$ Department of Podiatry, La Trobe University, Melbourne, Victoria, 3086, Australia. ${ }^{3}$ Department of Ambulatory Care, Liverpool Hospital, Locked Bag 7103, Liverpool, NSW, 2170, Australia.

Published: 20 May 2011

\section{doi:10.1186/1757-1146-4-S1-050}

Cite this article as: White et al:: Microbiology culture results in high risk foot clinic patients: an audit. Journal of Foot and Ankle Research 2011 4(Suppl 1):O50.
Submit your next manuscript to BioMed Central and take full advantage of:

- Convenient online submission

- Thorough peer review

- No space constraints or color figure charges

- Immediate publication on acceptance

- Inclusion in PubMed, CAS, Scopus and Google Scholar

- Research which is freely available for redistribution

Submit your manuscript at www.biomedcentral.com/submit
C Bïomed Central

\section{Biomed Central}

